\title{
Ruminococcus productus
}

National Cancer Institute

\section{Source}

National Cancer Institute. Ruminococcus productus. NCI Thesaurus. Code C86730.

A species of anaerobic, Gram positive, cocci shaped bacteria assigned to the phylum

Firmicutes. This species is catalase and indole negative, does not reduce nitrates and can

ferment cellobiose, arabinose, glucose and lactose. R. productus is found in the human intestinal flora and is not a known pathogen. 